\title{
Leder
}

\section{Kultur, privatliv og offentlighet: Religionens plass i det sekulariserte samfunnet}

\author{
Bjorn Myskja, Rune Nydal og Berge Solberg
}

Den dominerende oppfatningen i den politiske og moralfilosofiske tenkningen de siste tiår har vært at religion ikke bør spille noen avgjørende politisk rolle i det moderne sekulariserte demokrati. Religion tilhører privatsfæren, og politiske avgjørelser må fattes på et felles grunnlag, uavhengig av livssyn. De mest sentrale tenkerne i vår tids politiske filosofi, John Rawls og Jürgen Habermas, har begge i tidlige arbeider gitt uttrykk for at dette er en oppfatning som vil få en allmenn, global tilslutning, for de ser modernisering og sekularisering som to sider av samme sak. Det er nærmest to uunngåelige fenomen ettersom globalisering og modernisering vil føre til svekkelse av tradisjonelle kulturer og utbredelse av individualisme og demokratiske idealer. Bakgrunnen for dette temanummeret er at en rekke erfaringer fra de siste tiår har ledet til en gjenåpning av spørsmålet om religionens plass i sekulariserte samfunn.

\section{Religionens gjenkomst}

I motsetning til Rawls' og Habermas' tidlige antakelser ser religionens betydning i etiske og politiske spørsmål ut til å øke i store deler av verden. I USA, samt i store deler av Asia og Afrika, fortolkes fortsatt etiske og politiske spørsmål ved hjelp av religiøse normer og begreper, og tanken om at religionen vil gjennomgå en global privatisering etter europeisk mønster, ser lite sannsynlig ut. Men også i Europa skjer det endringer som byr på spe- 
sielle utfordringer. Flere av islamistene som sto bak terrorangrepene i USA i 2001, ble radikalisert i Tyskland. I Storbritannia har regjeringen godkjent begrenset bruk av sharia-domstoler i enkelte storbyer, og i den norske debatten framsettes udokumenterte påstander om at uoffisielle shariadomstoler har reell makt i bydelen Rosengård i Malmø. I disse dager diskuteres det videre om Norge skal tillate hijab, hodetørkle, for kvinner i politiet, noe som er uproblematisk i Sverige, men som ikke tillates for dansk politi. Andre debatter dreier seg om bruk av niqab, som skjuler deler av ansiktet, i skole og andre offentlige sammenhenger. Disse kontroversene viser at religionen ikke kan lukkes inne i det private rom, den trenger seg inn i offentligheten - uavhengig av sekularisering og verdipluralisme. Og den tar karakter av konfrontasjoner. Det tydeligste eksemplet på slik konfrontasjon er kanskje striden rundt Jyllands-Postens Muhammed-karikaturer, som diskuteres i Jonas Jakobsens bidrag i dette nummeret.

Charles Taylor analyserer sekulariseringens betydning for den moderne vestlige selvforståelse i sin nyeste bok, The Age of Secularity (2007). Ifølge Taylor er det en misvisende forenkling å hevde at sekularisering innebærer at religionen har mistet sin kraft og innflytelse som følge av at den er utkonkurrert av en vitenskapsbasert virkelighetsoppfatning som er mer i samsvar med det vi vet om virkeligheten. Sekulariseringen må forstås som et tredelt fenomen: det politiske skillet mellom stat og kirke, det sosiologiske faktum at langt færre tror og deltar i religiøse praksiser, og det kulturelle fenomen at gudstro ikke lenger er uproblematisk og selvsagt, men tvert imot ett valg blant mange. Dette siste punktet er viktig for å forstå hvorfor sekularisering ikke innebærer en erstatning av en utdatert virkelighetsforståelse: Religiøs tro er ikke først og fremst en framstilling av hva som eksisterer, og hvordan denne virkeligheten har oppstått. Religionen er primært en levemåte og en fortolkning av den menneskelige livserfaring, ikke en teori om verden. En ikke-religiøs humanisme er tilsvarende en måte å leve på, ifølge Taylor. Religion og ateisme står dermed ikke i et teoretisk konkurranseforhold, først og fremst, men uttrykker ulike livserfaringer som ikke er umiddelbart forenlige.

Dermed er vi plassert i det som Rawls har kalt «pluralismens faktum». Vi kan ikke lenger ta utgangspunkt i en felles livserfaring som retningsgivende for samfunnets felles lover og regelverk. I de nordiske land, og i resten av det som kalles «Vesten», består samfunnet av grupper med ulike og motstridende livssyn. Dersom ikke ett av disse har forrang, krever det toleranse. Ett enkelt livssyn kan ikke bli bestemmende for organiseringen av samfunnet. Sekularisering er altså ikke det samme som en overvinnelse av religionen, ifølge Taylor, men en prosess som innebærer en nyforståelse av religionens plass i en sekularisert politisk virkelighet. Habermas og Rawls hevder at et felles verdifundament må være grunnlaget for politiske avgjørelser i det moderne konstitusjonelle demokrati, ikke minst ideene om alle menneskers 
likeverd, tros- og talefrihet og individuelle menneskerettigheter. Men selv om man er enig $i$ at disse verdiene bør ha en spesiell status i den politiske prosessen, vil ikke dette nødvendigvis innebære at verdier som ikke deles av alle, bør holdes utenfor den politiske debatten. Tvert imot kan man ut fra Taylors analyser hevde at vi mister et vesentlig aspekt ved menneskelivet ved å utelukke religiøse erfaringer fra politiske diskusjoner og beslutninger. For dem som erfarer religion som en levemåte som gir en grunnleggende forståelse av livets mening, er det meningsløst å skulle skille mellom denne virkelighetsforståelsen og politiske spørsmål. For mange borgere gir religionen direkte eller indirekte svar på mange politiske spørsmål, selv om de har godtatt pluralismens faktum. De mener at det ikke følger at religionen er en privatsak.

Ut fra situasjonsbeskrivelsen over, kan det se ut som om det ikke er religionen generelt som motsetter seg privatisering, men islam. Det er imidlertid ikke riktig. Innen medisinsk etikk har argumenter med kristent opphav spilt en viktig rolle, til og med i stater der sekulariseringsidealet står sterkt. Særlig har religiøse grunnoppfatninger vært viktige i spørsmål knyttet til forskning på befruktede egg, reproduksjonsteknologi og eutanasi. I den forbindelse hevder Habermas i sine nyeste arbeider at religionen ser ut til å kunne artikulere noen intuisjoner som lett går tapt i en sekulær debatt. Han trekker særlig fram hensynet til sårbare grupper i samfunnet. Her tenker nok Habermas særlig på den jødisk-kristne tradisjonen slik den har påvirket den europeiske selvforståelsen også etter modernitetens gjennombrudd. Denne artikulasjonen kan særlig være viktig i en tid der de teknologiske mulighetene er så lysende at vi blir blendet for negative konsekvenser for svakere grupper i samfunnet. På den annen side vil mange hevde at religionens bidrag er et hinder for framskritt som vil komme alle til gode, og bekrefte etablerte maktforhold eller legitimere moralsk forkastelig voldsbruk. For eksempel har religiøs retorikk vært sterkt framme i de siste ti års legitimering av krigføring, på godt og vondt, noe som utdypes i Henrik Syses diskusjon av forholdet mellom kristen etikk og rettferdig krig-tradisjonen.

\section{Temanummerbidrag}

Religionen spiller en viktig rolle i det sekulære samfunnet, enten man liker det eller ikke. Det kommer klart til uttrykk i de senere årenes politiske så vel som filosofiske litteratur, tydelig eksemplifisert ved arbeidene til blant andre Taylor og Habermas. Det er derfor også rimelig at Habermas' tenkning er et viktig bakteppe for to av artiklene i dette nummeret. Jakobsens diskusjon av striden rundt de danske Muhammed-karikaturene argumenterer med Habermas at det påligger religiøse grupper som opplever disse 
tegningene som et utillatelig overtramp, å forsøke å oversette sine religiøse argumenter til en allment tilgjengelig form. Det innebærer at argumentene må sekulariseres. Dette kravet er imidlertid bare moralsk og pragmatisk, det er ikke en forutsetning for å delta i debatten. Dermed kan ikke et slikt oversettelseskrav pålegges ved lov. En kan heller ikke sette grensene for hva som er utillatelige former for blasfemiske krenkelser, og hva som må tillates ut fra prinsippene om religions- og ytringsfrihet. Det må fastsettes på grunnlag av en åpen debatt med bred deltakelse, ifølge Jakobsen. Der Jakobsen går utover rammene til Habermas, er i spørsmålet om hvilke krav på særbehandling en minoritet kan påberope seg overfor storsamfunnets kulturelle press. Her benytter Jakobsen Axel Honneths teori om betydningen av anerkjennelse som grunnlag for samfunnsmessig integrering. Krenkelser har politisk betydning, for uten full anerkjennelse i det offentlige rom, vil heller ikke minoriteter ha mulighet til å delta og bidra til samfunnet. Det innebærer imidlertid ikke at minoritetene må ha spesiell lovbeskyttelse, for krav om gjensidig anerkjennelse er først og fremst moralske krav.

Også Roe Fremstedal tar for seg Habermas' teori om religionens plass i det offentlige rom, men da i første rekke gjennom en analyse av Habermas' syn på religionens rasjonalitet. Fremstedal hevder at Habermas står i et spenningsforhold mellom Kants syn på religionen som en del av den menneskelige rasjonalitet idet den begrenses av fornuftens moralpåbud, og Kierkegaards personlige åpenbaringsbaserte religionsforståelse. Til tross for Habermas' klare kantianske røtter, påpeker Fremstedal vesentlige likhetstrekk med Kierkegaard. Kilder til religiøs overbevisning, som den religiøse erfaring, blir hos Habermas forstått å ha en delvis eksistensiell karakter som ikke uten videre kan kommuniseres fornuftsmessig. Dersom den livgivende kilden til mening og kraft, slik Habermas poetisk beskriver den religiøse tro, holdes utenfor det fornuftsmessige fellesskap, ser det ut til å innebære en avgjørende begrensning på muligheten for oversettelse av de religiøst motiverte argumenter til allment tilgjengelig form. Gitt denne forståelsen vil den religiøse borger aldri kunne oppnå en full likestilt deltakelse i den politiske samtalen, noe som er en vesentlig begrunnelse for Habermas' refortolkning av religionens rolle i politisk debatt. Må vi allikevel velge mellom alternativene Habermas prøver å unngå: enten en avvisning av reelle religiøse argumenter i offentlig debatt fordi de ikke kan oversettes uten å miste sin essens, eller aksept av at religiøs begrunnelse må godtas også $\mathrm{i}$ politiske beslutninger? Det spørsmålet står åpent etter Fremstedals analyse.

Habermas hevder, i likhet med Taylor, at den jødisk-kristne tradisjon er en forutsetning for det sekulariserte demokrati. Dette opphavet finner vi igjen i mange av de normative grunntrekkene ved det moderne samfunnet i sekularisert form. Henrik Syse tar opp ett av disse feltene, nemlig diskusjonen om de moralske grensene for legitim krigføring. Han hevder at rettferdig krig-tradisjonens religiøse røtter også kan gjenfinnes i den sekulariserte 
versjonen av argumentene. Dette er ikke selvsagt, for det fantes diskusjoner om moralsk krigføring før og uavhengig av den kristne kulturkretsen. I tillegg er det kristne politikere og statsledere som ikke har fulgt tradisjonens moralske pålegg og likevel hevdet at de har handlet i tråd med sin tro. Til slutt er det også slik at krigens moral gjør krav på allmenngyldighet, og det lar seg vanskelig forene med en religiøs begrunnelse i en pluralistisk virkelighet. Like fullt er det flere distinktivt kristne elementer i denne tradisjonen, ifølge Syse. For det første forutsetter tradisjonen et historiesyn som sammenfaller med Augustins. Likedan er tradisjonens syn på drap nært knyttet til et kristent menneskesyn. Til slutt er også den kristne oppfatningen av synd og nåde et bakteppe for den sekulariserte versjonen av rettferdig krig. Så selv om krigens moral kan ha mange opphav, hevder Syse en bevissthet på dens kristne røtter kan gi en bedre forståelse av hvorfor moralsk krigføring er påkrevet.

\section{Bidrag i nummerets åpne del}

I den første artikkelen i den åpne delen av dette nummeret beveger vi oss over fra tro til medisin, nærmere bestemt til nasjonale screeningprogrammer for kreft. Enkelte vil nok hevde at overgangen fra tro til nøktern empiri ikke behøver å være så stor, fordi de harde kontroversene som har vært rundt for eksempel mammografiscreening i mange år, synes å dele verden inn i troende eller ikke-troende når det gjelder screening. Men Fía Lindenskov, John Brodersen, Lonny Henriksen og Peter Laurs Sørensen er ikke primært opptatt av om screening reduserer dødelighet og sykelighet eller ei, men snarere om det er etisk forsvarlig at nasjonale screeningprogrammer innføres med gulrot og pisk. Med andre ord stiller de spørsmål til samtykket og frivilligheten ved deltakelse i screeningprogrammer hvor man belønnes dersom man deltar, og eventuelt møter sanksjoner dersom man ikke deltar. Forfatterne tar utgangspunkt i en tysk virkelighet hvor deltakelse i screeningprogrammer belønnes av den tyske stat, og de undersøker deretter holdningene hos sentrale danske aktører til om de ønsker en slik helsepolitikk. Forfatterne blir styrket i sin uro for at viktige verdier står på spill. De ser for seg en framtid hvor kreftsyke blir møtt med manglende respekt fordi de ikke har deltatt i de screeningprogrammene de burde. Hva er så det viktigste argumentet hos Lidenskov et al. for at det er uetisk å knytte belønning/sanksjoner til screeningprogrammer? Deres gjentatte poeng er at slike programmer har skadelige virkninger. Screening gir falske positive svar, overdiagnostisering, falsk trygghet og en rekke andre mulige skadelige virkninger. I tillegg har informasjonen i screeningprogrammer en tendens til å underslå negative sider og overdrive positive effekter av screening. Samtykket som gis til screening, er altså veldig ofte ikke informert, etter forfatter- 
nes mening. Men forfatterne går også et skritt lenger: Gitt at det ikke skulle kunne påvises noen negative helseeffekter av screening, så vil fremdeles gulrot/sanksjoner være uetisk å lokke eller true med. Det begrunnes med at det ikke er helsevesenets oppgave å favorisere en bestemt oppfatning av det gode liv.

Meningene om screening er sterke og mange. Derfor har vi valgt å invitere Geir Hoff i det norske Kreftregisteret til å kommentere artikkelen til Lindenskov et al., og vi har også gitt forfatterne anledning til å komme med et kort tilsvar. Hoff er tilhenger av å innføre screening for tarmkreft i Norge, og han påpeker viktigheten av evidens og saklig informasjon om både fordeler og ulemper. I disputten mellom Hoff og Lidenskov et al. oppstår en viktig etisk-metodologisk problemstilling: Kan egentlig randomiserte studier gi evidens for skadelige virkninger av screening? Eller må det andre studiedesign til - design som i medisinens øyne ikke har vært å forstå som fullverdig forskning? I så fall ligger det også en vitenskapskontrovers innbakt i spørsmålet om screening gir mer nytte enn skade, og hvordan folk skal informeres og respekteres.

Mens holdningene til medisinsk teknologi nok i overveiende grad er positive blant befolkningen i Norden, så er ikke det samme tilfelle når det gjelder en annen teknologi - nemlig moderne bioteknologi i matproduksjon. I den andre artikkelen i dette nummerets åpne del viser Trine Magnus, Reidar Almås og Reidun Heggem at selv etter 20 års debatt om genmodifisert mat (GMO), er fremdeles norske forbrukere skeptiske. Hele 44 prosent svarer at de verken vil kjøpe eller spise slik mat. Mange biologer har sett denne skepsisen som et uttrykk for mangel på kunnskap. Magnus et al. avviser imidlertid denne fortolkningen. Gjennom målinger av forbrukernes holdninger og tolkninger av deres svar, kommer de fram til at flertallet heller avveier nytte mot risiko: Forbrukere er villige til å spise genmodifisert mat den dagen miljøargumentene er sterkere enn risikoargumentene. I Norge så vel som i Danmark, er de yngste forbrukerne mest på gli i GMOspørsmålet. Dersom den generelle holdningen er at man ikke bør spise genmodifisert mat før man vet at det gagner miljøet og egen helse, trenger ikke en slik innstilling være uttrykk for manglende kunnskap, men snarere et uttrykk for en etisk gjennomtenkt holdning. 